\title{
THE EFFECT OF ACCULTURATION ATTITUDE ON SECOND-HAND CLOTHES PURCHASES
}

\author{
Halimin Herjanto* \\ University of The Incarnate Word \\ Heris Hendriana \\ IKIP Siliwangi Bandung
}

\begin{abstract}
Traditionally, second-hand clothes (SHC) are viewed as non-valuable items that exclusively belong to the lower social class. Today, SHC have become a new global fashion trend and a new business phenomenon. This study explores the effect of acculturation attitudes on SHC adoption intention and behavior. The survey outcomes from 300 Indonesian respondents show that proactive and reactive attitudes affect SHC adoption intention and behavior differently. In addition, intention is found to significantly affect SHC buying behavior. In this article, we discuss these findings and implications. The findings of this study are important because the SHC phenomenon is increasing significantly and SHC are predicted to become even more popular in the years to come.
\end{abstract}

Keywords: Second-hand clothes; Proactive and reactive acculturation attitude; Income; Intention and adoption behavior.

Received: 21 July 2019

Accepted: 30 January 2020

\section{INTRODUCTION}

Although the modern form of globalization began at the beginning of the 19th century (O'Rourke \& Williamson, 2004), the integration and liberalization of global financial markets did not start until 1990 (Rajan, 2001). Such liberalization allows developing countries to access capital flows from the global community (World Bank, 2000) to create an efficient market and to improve the income level and living standard of their citizens (Kapila, 2002). In addition, globalization offers the free influx of information (Collins, 2005) which improves intercultural connectivity (Osland, 2003) and generates homogeneous global consumer consumption patterns (Manrai \& Manrai, 2011), such as second-hand, Western style clothes adoption (Wisnuwardhani et al., 2015).

Watson et al.'s (2016) study on the used clothes industry in Nordic countries found that secondhand clothes offer environmental and social-economic benefits to global society. Environmentally, SHC help the planet by reducing water consumption by 18 billion gallons of water and eliminating nearly 200,000 tons of CO2 annually by offsetting the production of new textile materials. SHC also save precious space by reducing unused clothes landfill, as well as reducing noise pollution

\footnotetext{
* Corresponding author: H-E-B School of Business and Administration, University of The Incarnate Word, 4301 Broadway, San Antonio, TX, 78209, U.S.A. Tel. 1-210-283-5031. Email: herjanto@uiwtx.edu.
} 
from textiles machineries, exploitation of animals, over usage of natural resources, the disturbance of the ecological balance and more importantly, food contamination because of the overuse of chemicals when dyeing textiles (Challa, 2018). Socio-economically, SHC produce new jobs, improve government revenues and encourage creativity (Watson et al., 2016). In addition, SHC save money, offer unique, rare and vintage products (Herjanto et al., 2016) and help people maintain a stylish appearance (Yan et al., 2015) and higher self-image (Tian et al., 2001).

As a response to such benefits, consumers have developed a higher demand for SHC and consequently, global SHC sales is expected to reach USD 400 billion by 2022 (Van Elven, 2018). Kestenbaum (2018) argues this trend is predicted to grow more quickly in the years to come. The trend shows that SHC have become an important new global business phenomenon (Herjanto et al., 2016) and attracted scholars to investigate SHC from different angles. For example, Toplis (2010) took the initiative to explore the history of SHC. Scholars have also examined the challenges in adopting SHC (Chalhoub, 2012), disposal SHC behavior (Farrant et al., 2010) and consumer motivation to purchase SHC (Herjanto et al., 2016). Despite these efforts, however, the findings are inconclusive (Felix et al., 2013) and only touch the tip of this phenomenon (Na'ameh $\&$ Al Huban, 2012). Thus, to have a better understanding, SHC investigation should be extended (Herjanto et al., 2016).

The present study, therefore, aims to answer the above call to expand the understanding of the SHC phenomenon by investigating the effect of acculturation attitude on SHC adoption intention and behavior. This study is organized as follows: first, we present a brief discussion on the SHC trend in Indonesia, along with the concepts of acculturation attitude. Second, we offer our hypotheses. Third, we discuss our methodology. Fourth, we present a discussion on our findings and lastly, we provide our conclusion, limitations of this study and future research directions.

\section{LITERATURE REVIEW}

\section{1. $\quad S H C$ in the Indonesian context}

Because of high global commodity prices and high domestic household consumption (World Bank, 2017a), Indonesia, the world's fourth most populated nation, experienced an increased 5.1\% GDP in 2017 and is expected to maintain this growth in the years ahead (IMF, 2018). In total, 43\% of total household consumption is generated by the Indonesian middle-class (World Bank, 2017b) and on average, they spend approximately $58 \%$ of their disposable income on leisure and small luxury items (Nikkei Asian Review, 2015) such as cheap Chinese brand smartphones, coffee at Starbucks (Sharpe, 2014) and branded SHC (Karimah \& Syafrizal, 2014).

According to the 2015 annual report of the Indonesian Ministry of Trade, Indonesia imported SHC from France, Singapore, the Netherlands, the U.S.A. and South Korea, with a value of USD 3.3 million. This data shows that Indonesian people do not view SHC as low-level fashion; rather, they view $\mathrm{SHC}$ as a tool that allows them to follow the modern global fashion trend and consequently, customers from different backgrounds, including top artists, comfortably wear SHC in the public arena (Saputra, 2015). According to Wisnuwardhani et al. (2015), a combination of existing supply, access to information and customer psychology generate the high demand and popularity of SHC. 
Although these dimensions are important and inseparable, Ryding et al. (2017) suggest that the dimension of customer psychology, such as intention, serves as the most significant driver to increase SHC adoption. However, this dimension is unique and differs according to a customer's attitude (Ajzen, 2011). Kjeldgaard (2002), Saffu and Walker (2006) and Gbadamosi (2012) argue that acculturation attitude is one of the most important attitudes to motivate customers' adoption of SHC. Despite this, Gbadamosi (2012) notes that the study of acculturation attitude in the SHC context is imperfect and calls for future researchers to investigate it further. Thus, this research aims to extend our understanding of the SHC phenomenon by investigating the effect of proactive and reactive acculturation attitude in the context of Indonesia.

\section{2. $\quad$ SHC Adoption behavior}

Our study refers to SHC as branded second-hand clothes, excluding gloves, underwear, shoes and jewelry. SHC adoption behavior is part of green purchase behavior (D'Souza et al., 2007) and is considered to be ethical behavior (De Pelsmacker et al., 2005). Herjanto et al. (2016) suggest that the history of SHC started in the mid-1300s and that SHC adoption is complex and multifaceted. According to Na'amneh and Husban (2012), one of the reasons for such complexities is that SHC adoption is related to individual internal and external psychological motivation. Internally, SHC adoption can be explained through identity theory. According to identity theory, an individual generally tries to portray him/herself as a unique individual that fits into a certain group or society (Stets \& Burke, 2000). This theory asserts that the degree of an individual's fitness with a preferred group guarantees his or her acceptability and survivability. Traditionally, SHC was exclusively consumed by the under-privileged class, however, in today's society, SHC is perceived as a tool to show an individual's creativity (Tanrisever, 2015) and uniqueness (Cervellon et al., 2012) and more importantly, it serves as a reflection of an individual's support of the environment (Farrant et al., 2010). For example, by wearing SHC, an individual is viewed as an environmental supporter and therefore, he or she is accepted and welcomed by people or groups with similar views.

On the other hand, subjective norm theory helps explain an individual's external motivation to adopt SHC. According to this theory, an individual's SHC adoption is dependent on the degree he or she perceives pressure from others (Wan et al., 2017). In other words, the more an individual perceives pressure to wear SHC, the greater the likelihood the individual will adopt SHC. Today, sustainable fashion campaigners have actively raised awareness of the benefits of SHC and more importantly, they work closely with high profile celebrities such as Sarah Jessica Parker and Drew Barrymore to encourage individuals to adopt SHC (ThredUp, 2016). Herjanto et al. (2016) argue that the combination of external and internal motivation shape and improve an individual's positive attitude toward SHC adoption.

Attitude refers to an individual's favourable or unfavourable evaluation of SHC (Eagly \& Chaiken, 1993). According to grand consumer behaviour theories such as the Theory of Planned Behaviour, the Theory of Reasoned Action, Theory of Acceptance Model and the Theory of Trying, attitude is the chief psychological component that directly affects an individual's intention and indirectly influences SHC adoption behaviour. Adopting new objects or behaviours require an individual's social, psychological, financial and cultural adjustment (Avlonitis \& Gounaris, 1997). Among these factors, Hansen (1999) suggests that transcultural adjustment is very important in producing 
a positive attitude toward SHC. According to Berry (1992), this process of adaptation that accompanies culture is known as acculturation attitude.

\section{3. $\quad$ Acculturation Attitude}

Acculturation refers to cultural adjustment and adaptation (Ebin et al., 2001). It occurs when both local and foreign residents find a cultural balance because of continuous interactions and exposures to each other's culture (Berry, 2003). Berry (2005) suggests that acculturation can be both proactive and reactive. Proactive acculturation develops when individuals integrate or assimilate a new culture into their native culture, whereas reactive acculturation occurs when individuals separate from or deny the adoption of a new culture. These different dimensions of acculturation influence individuals' motivation and behavior differently (Saffu \& Walker, 2006). For example, in proactive acculturation, individuals tend to follow fashion trends such as consuming SHC, whereas in reactive acculturation, individuals tend to avoid fashion trends including the adoption of SHC.

The concept of proactive acculturation is viewed as individuals' high degree of openness and willingness to interact with, try and adopt new things. This definition shows that highly acculturated individuals attempt to assimilate into their new society by becoming more similar with others (Ogden et al., 2004). One of the easiest ways to assimilate into a new society is to adopt others' behaviors, for example, how they speak and how they dress up (Connor et al., 2017). Adopting SHC allows such highly acculturated individuals to appear similar and to become more socially accepted. Because of such a positive experience, highly acculturated individuals tend to have a higher buying intention toward SHC. Thus, we hypothesize:

\section{Hla: Proactive acculturation positively affects SHC buying intention.}

By adopting SHC, highly acculturated individuals show their genuine motivation to become a new member of an adopted society. This willingness to become similar reduces anxiety, suspicion and uncertainty. According to Gaur et al. (2017), displaying such proactive acculturation helps individuals to gain a higher understanding of the society and such understanding enhances a sense of belongingness, respect and closer relationships. Because of such benefits, highly proactive, acculturated individuals ultimately have higher buying intentions toward SHC, which in turn generates SHC adoption behavior. Thus, we hypothesize:

\section{H1b: Proactive acculturation positively affects SHC buying behavior.}

Reactive acculturation demonstrates individuals' resistance to or rejection of the adoption of a new culture (Owaka, 2015). For example, Presley and Campassi (2013) suggest that highly reactive acculturated individuals tend to have a lower intention to consume foreign clothing styles. According to Bilge (2012), such resistance occurred because reactive acculturation processes produce fear and feelings of exclusion, and to overcome this negative situation, individuals tend to consolidate and strengthen their own culture by adopting and revitalizing their traditions. To highly reactive acculturated individuals, the adoption of Western SHC is regarded as an attempt to replace their own tradition and a betrayal of and threat to their native culture. In other words, SHC adoption is seen as a threat to their survival that should be eliminated or rejected. Because of this perception, 
highly reactive acculturated individuals develop a negative SHC buying behavior. Thus, we hypothesize:

\section{H2: Reactive acculturation negatively affects SHC buying behavior.}

Intention is conceptualized as a barometer that shows how hard people are willing to try and how much effort they are sacrificing to conduct certain behaviors (Rizwan et al., 2014). Thus, intention is a true reflection of individuals' internal desire to participate or to perform the behavior in question (Nik Abdul et al., 2009). According to Wu et al. (2015), the degree of internal desire varies and depends on individuals' interest in adopting the behavior in question and more importantly, individuals' ability to adopt such behavior. In the SHC context, D'Souza et al. (2007) explain that individuals' interest and ability to adopt SHC is driven by the quality and cost of SHC products. They argue that the higher the quality and the lower the price, the more the internal desire to adopt SHC. Based on this argument, Ajzen (2011) concludes that the higher the internal desire, the higher the intention to adopt SHC. Thus, based on this argument, we hypothesize:

H3: Stronger SHC buying intention leads to increased SHC buying behavior.

Figure 1: The Conceptual Model of This Research

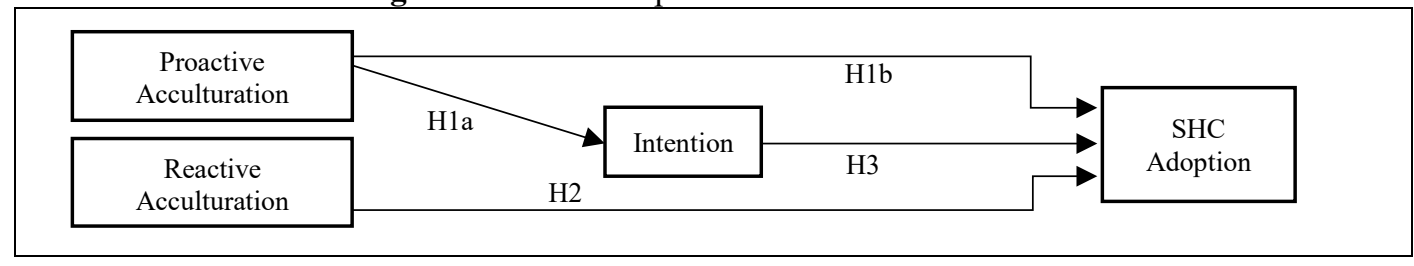

\section{METHODOLOGY}

\subsection{Research Setting:}

To test our hypotheses, we distributed 450 structured questionnaires in the city of Bandung, Indonesia. The city of Bandung was selected not only because it is the fourth largest city in Indonesia, but also because it is known as the most vibrant, tolerant and progressive city, with $70 \%$ of the population aged between 15 and 59. As this study seeks to understand SHC adoption, it was necessary to put some restrictions on the sampling frame. First, individuals younger than 20 were excluded from this study. Second, individuals who had never worn SHC were also ruled out since it was unlikely these individuals would have had enough opportunity to receive the benefits of SHC. Finally, to ensure that the questionnaires were filled out correctly, only people who were competent in the Indonesian language were invited to participate in the study. A total of 357 questionnaires were collected; however, only 300 questionnaires were fully completed and usable. In total, $41.5 \%$ of respondents were male, $58.5 \%$ were female and $93 \%$ of respondents were $20-39$ years old. In total, 5.5\% were unemployed, $23.7 \%$ were students, $51.5 \%$ were employed and $19.3 \%$ were self-employed. In addition, $68 \%$ of respondents were native Indonesian, 19\% were ChineseIndonesian, $5 \%$ were foreign nationals and $8 \%$ were undisclosed. 
Table 1: Respondent Profile

\begin{tabular}{lccc}
\hline \hline Demographic - Age & Frequency (\%) & $\begin{array}{c}\text { Demographic - Income } \\
\text { (Rupiah) }\end{array}$ & Frequency (\%) \\
\hline 20 & $27(9)$ & $0-100,000$ & $9(3)$ \\
$21-29$ & $142(47.3)$ & $101,000-500,000$ & $18(6)$ \\
$30-39$ & $117(39)$ & $501,000-1,000,000$ & $49(16.3)$ \\
$40>$ & $14(4.7)$ & $1,000,001-5,000,000$ & $115(38.3)$ \\
\hline \hline
\end{tabular}

\subsection{Measures}

All the scales were adopted from the published literature and modified to the context of this study. Because the data-collection was carried out in Indonesia, the authors adopted McGorry's (2000) double translation procedure. The questionnaire was first translated into Indonesian by two independent language translators, then both versions were re-translated to English with two different independent language translators. The scales were borrowed and modified from existing scales. For example, proactive and reactive acculturation scales were borrowed from Herjanto (2014), SHC buying intention from Nameghi and Sahdi (2013) and SHC buying behavior from Kim (2011). The scales employed multi-item, seven-point Likert-type scales anchored at Strongly Disagree to Strongly Agree. These scales showed good reliabilities (0.76- 0.92) and factor loadings $(0.61-0.91)$. Table 2 . Shows psychometric property of this present study.

Table 2: Psychometric Property

\begin{tabular}{|c|c|c|c|}
\hline Items & Mean & $\lambda$ & $\alpha$ \\
\hline \multicolumn{4}{|l|}{ Proactive acculturation } \\
\hline $\begin{array}{l}\text { I typically speak in his/her native language when I discuss my SHC } \\
\text { behavior with others. }\end{array}$ & 3.229 & 0.610 & 0.812 \\
\hline I typically speak in his/her native language during my SHC transaction & 4.056 & & \\
\hline with others. & 3.957 & 0.814 & \\
\hline I get along better with other SHC users & 3.841 & 0.907 & \\
\hline I understand other SHC users well & & 0.887 & \\
\hline \multicolumn{4}{|l|}{ Reactive acculturation } \\
\hline I prefer to share my SHC needs with people from own ethnic background & 2.568 & 0.825 & 0.917 \\
\hline $\begin{array}{l}\text { I feel other SHC users of my own ethnicity treat me as equal more so than } \\
\text { do other SHC users from different ethnic backgrounds }\end{array}$ & 2.591 & 0.778 & \\
\hline I prefer to deal with other SHC users from my ethnic culture. & 2.535 & 0.905 & \\
\hline I get along better with other SHC users from my ethnic culture. & 2.628 & 0.902 & \\
\hline I feel more relaxed dealing with other SHC users of my ethnic culture. & 2.522 & 0.852 & \\
\hline \multicolumn{4}{|l|}{ Intention } \\
\hline I plan to reuse SHC whenever possible. & 3.173 & 0.882 & \\
\hline I will try to reuse SHC if they can be reused. & 3.380 & 0.885 & \\
\hline \multicolumn{4}{|l|}{ Adoption Behavior } \\
\hline I have switched my clothes to SHC. & 2.593 & 0.830 & 0.757 \\
\hline I make a special effort to buy SHC. & 2.413 & 0.890 & 0.824 \\
\hline When I have a choice between two equal products, I purchase SHC. & 2.460 & 0.739 & \\
\hline
\end{tabular}

Notes: $\lambda=$ factor loadings and $\alpha=$ Cronbach alpha scores 


\section{RESULTS AND DISCUSSION}

We tested our hypotheses using Ordinary Least Square regression. As reported in Table 3, the proactive acculturation attitude $(\beta=0.142, \mathrm{p}=0.014)$ positively influenced SHC buying intention. Hence, hypothesis H1a is supported. Further, we tested the direct effect of proactive and reactive acculturation attitude and intention on SHC adoption behavior. The result showed that proactive acculturation attitude $(\beta=-0.204, p=0.000)$ and intention $(\beta=0.156, p=0.002)$ positively influenced SHC buying behavior, whereas reactive acculturation attitude $(\beta=0.411, p=0.000)$ was found to significantly and negatively affect SHC buying behavior. These results support hypotheses $\mathrm{H} 1 \mathrm{a}, \mathrm{H} 1 \mathrm{~b}, \mathrm{H} 2$ and $\mathrm{H} 3$. A discussion of these findings and their implications are presented in the next section.

Table 3: Results of OLS Analysis

\begin{tabular}{|c|c|c|c|c|}
\hline & DV: Intention & & DV: Behaviour & \\
\hline Variables & $\begin{array}{c}\text { Unstandardized } \\
\text { beta } \\
\text { coefficient } \\
\end{array}$ & Standard Error & $\begin{array}{l}\text { Unstandardized beta } \\
\text { coefficient }\end{array}$ & Standard Error \\
\hline Constant & 2.697 & $0 . .240$ & 1.817 & 0.381 \\
\hline Proactive & $0.154 *$ & 0.062 & $-0.302 * * *$ & 0.076 \\
\hline Reactive & & & $0.433 * * *$ & 0.054 \\
\hline Intention & & & $0.214 * *$ & 0.070 \\
\hline $\mathrm{R}$ squared & 0.020 & & 0.238 & \\
\hline $\mathrm{F}$ & 6.128 & & 30.881 & \\
\hline
\end{tabular}

$* \mathrm{P}<0.05, * * \mathrm{P}<0.01, * * * \mathrm{P}<0.001$

The effect of proactive on SHC buying intention.

As stated in the hypotheses, we predicted that a proactive acculturation attitude would positively affect SHC buying intention. The findings of this study showed that the effect of a proactive acculturation attitude on SHC buying intention is positive and significant. The main purpose of an individual with a proactive acculturation attitude is to integrate or assimilate a new culture into his or her own native culture. As members of a new culture, Indonesians with a highly acculturated attitude tend to copy global culture's way of life, and this includes following new trends such as wearing SHC. Wearing SHC is not only viewed as one way to maintain their membership, but more importantly, represents individuals' openness, positivity and readiness for new opportunities (Kim, 2001) without spending too much of their limited funds. Therefore, for highly proactive acculturated individuals, SHC adoption is a survival tool. Thus, in this situation, highly acculturated individuals tend to have a higher intention toward SHC. These findings lend support to Kharullah and Kharullah (1999) who found that highly acculturated Asian-Indian immigrants in New York had a higher purchase intention toward American shampoo and suits.

\section{The effect of proactive and reactive acculturation and intention on SHC buying behavior}

Our findings showed that proactive and reactive acculturation attitude and intention have an important effect on SHC buying behavior. As discussed earlier, highly proactive acculturated individuals have a strong desire to maintain a harmonious relationship with their society. To do that, such individuals tend to be more tolerant of a new culture and more willing to modify their 
way of life to become similar to others within the new culture. This includes wearing SHC. Today, SHC serve as an important communication tool, as well as a barometer to justify people's acculturation status. Thus, for highly proactive acculturated individuals, wearing unique SHC becomes a good strategy to penetrate and become a member of the new society. For example, the middle-class views SHC as a tool that allows them to become part of the global fashion culture. In order to become a group member of this culture, highly proactive acculturated individuals tend to fill their wardrobe from alternative sources including SHC. This finding confirms the study of Huang and Liu (2016) who found a positive direct association between highly acculturated Chinese individuals on entertainment consumption in China.

In addition, reactive acculturation attitude was found to negatively affect SHC buying behavior. Behavior is a tangible act (Bock \& Borders, 2012), which means people can see how other people behave, then judge this behavior and to some extent experience the outcome of such behavior (Dennis \& Hayes, 2012). People with a higher reactive acculturation attitude view the adoption of SHC as unacceptable behavior that should be avoided. They consider the wearing of SHC as a public abandonment of one's own culture, that is, as a form of betrayal of culture that ruins the wearer's self-image. For this reason, people with a higher reactive acculturation attitude avoid buying SHC. This result lends support to the study of Kiylioglu and Wimmer (2015) who discovered that young Turkish immigrants in Austria with a highly reactive acculturation attitude experienced higher self-esteem and a better self-image when able to read Turkish books.

Extant psychology and the marketing literature have shown that the relationship between intention and behavior is very strong. Our study confirmed that SHC buying intention is responsible for higher SHC buying behavior. As discussed by Koe et al. (2012), intention is a strong indicator of behavior. However, Ajzen (1991) suggests that the effect of intention on behavior is determined by individuals' predetermined decisions and resources (e.g., time, knowledge and memberships etc.), which further serve as the primary controls of behavior. In this context, proactive acculturation can be considered as a resource because it reflects community membership. Based on this explanation, therefore, individuals with a higher proactive acculturation attitude elicit approval from their community to continue their integration. Therefore, for this reason, individuals with a higher proactive acculturation attitude tend to have higher SHC buying behavior.

\section{LIMITATIONS AND FUTURE RESEARCH}

Although this study extends our understanding of the SHC adoption phenomenon, it has several limitations. First, this study collected data from residents in the Bandung area only. Because of this limited focus area, generalization of the findings should be made with caution. Second, this study was carried out in the SHC context; therefore, the findings may not be applicable to other green industry contexts. Third, the majority of the survey respondents were native Indonesian, and other ethnicities were under-represented. The findings may therefore be skewed to the native Indonesian perspective. Future research, therefore, may address this limitation by including multiple ethnicities as well as different regions to provide a different perspective on the SHC phenomenon. In addition, our study only employed a single acculturation component (proactive and reactive acculturation), which may have resulted in an oversimplification of the concept of acculturation. Future research may include a full range of acculturation components as well as other variables such as national identity as potential moderators. 


\section{CONCLUSION AND IMPLICATIONS}

SHC adoption has gained momentum in Indonesia and created a massive business opportunity. This study found that SHC buying behavior was significantly and positively affected by a proactive acculturation attitude as well as the intention to buy SHC. This suggests that it is important for SHC vendors to maintain customers' proactive acculturation attitude as well as their SHC buying intention. To do that they need to highlight the psychological benefits of SHC, such as a higher self-image. This is because SHC offers a higher sense of similarity and a stronger sense of belonging within a growing middle-class society. This study extends SHC studies and fills the gap in the literature by consolidating the construct of acculturation attitude and investigating the impact on SHC buying behavior.

\section{REFERENCES}

Ajzen, I. (1991). The theory of planned behavior. Organizational Behavior and Human Decision Process, 50(2), 179-211.

Ajzen, I. (2011). The Theory of planned behavior: Reactions and reflections. Psychology \& Health 26(9), 1113-1127.

Avlonitis, G. J., \& Gounaris, S. P. (1997). Marketing orientation and company performance: Industrial vs. Consumer goods companies. Industrial Marketing Management, 26(5), $385-402$.

Berry, J. W. (2003). Conceptual approaches to acculturation. In K. Chun, P. Balls-Organista, \& G. Marin (Eds.), Acculturation: Advances in theory, measurement and application (pp. 17 37). Washington, DC: APA Books.

Berry, J. W. (2005). Acculturation: living successfully in two cultures. International Journal of Intercultural Relations, 29(6), 697-712.

Bilge, H. N. (2012). Meskhetian Turks: Exploring identity through connection of culture. (Doctor of Philosophy thesis. Arizona State University). Retrieved from https://search-proquestcom.ezproxy.aut.ac.nz/pqdtglobal/docview/1010270332/previewPDF/1E392178F4294E CFPQ/1 ?accountid $=8440$.

Bock, S. J., \& Borders, C. (2012). Effective practices/ interventions for students with emotional and behavioral disorders. In J.P. Bakken, F.E. Obiakor \& A.F. Rotatori (Eds.), Behavior disorders: Practice concerns and students with EBD (pp. 61-82). Bingley, UK: Emerald Group

Cervellon, M. C., Carey, L., \& Harms, T. (2012). Something old, something used. International Journal of Retail \& Distribution Management, 40(12), 956-974.

Chalhoub, H. (2012). From recyclers to risk takers: The social, economic and political challenges of selling second hand clothes in Kenya (ISP Paper No. 1387). Retrieved from http://digitalcollections.sit.edu/cgi/viewcontent.cgi?article=2409\&context=isp_collectio n.

Challa, L. (2018). Impact of textiles and clothing industry on environment: Approach towards ecofriendly textiles. Retrieved from https://www.fibre2fashion.com/industryarticle/1709/impact-of-textiles-and-clothing-industry-on-environment-approachtowards-eco-friendly-textiles\#: :text=Most $\% 20$ of $\% 20$ the $\% 20$ textile $\% 20$ machineries, industry $\% 20$ are $\% 20$ of $\% 20$ sub $\% 2 \mathrm{D} \% 20$ standard. 
Collins, M. (2005). The pros and cons of globalization. Retrieved from https://www.forbes.com/sites/mikecollins/2015/05/06/the-pros-and-cons-ofglobalization/\#3f180c2fccce.

Connor, H., Ayallo, I., \& Elliott, S. (2017). African mothers' experiences of raising “Afro-Kiwi kids" in Aotearoa/New Zealand. Australasian Review of African Studies, 38(2), 87-107.

D’Souza, C., Taghian, M., \& Khosla, R. (2007). Examination of environmental beliefs and its impact on the influence of price, quality and demographic characteristics with respect to green purchase intention. Journal of Targeting, Measurement and Analysis for Marketing, 15(2), 69-78.

De Pelsmacker, P., Diresen, L., \& Rayp, G. (2005). Do consumers care about ethics? Willingness to pay for fair-trade coffee. Journal of Consumer Affairs, 39(2), 363-385.

Dennis, R., \& Hayes, B. D. (2012). Matching your organizational culture to the safety mission. Occupational Health \& Safety, 81(3), 46-48.

Eagly, A. H., \& Chaiken, S. (1993). They psychology of attitudes. Fort Worth, TX: Hartcourt, Brace, Jovanovich.

Ebin, V. J., Sneed, C. D., Morisky, D. E., Rotheram-Borus, M. J., Magnuson, A. M., \& Malotte, C. K. (2001). Acculturation and interrelationships between problem and health promoting behaviors among Latino adolescents. Journal of Adolescent Health, 28(1), 62-72.

Farrant, L., Olsen, S. I., \& Wangel, A. (2010). Environmental benefits from reusing clothes. International Journal Life Cycle Assessment, 15(7), 726-736.

Felix, A. T., Asuamah, S. Y., \& Darkwa, B. (2013). Are demographic variables determinants of recycling behavior in Ghana? International Journal of Innovative Research \& Development, 2(7), 381-387.

Gaur, S. S., Sharma, P., Herjanto, H., \& Kingshott, R. P. J. (2017). Impact of frontline service employees' acculturation behaviors on customer satisfaction and commitment in intercultural service encounters. Journal of Service Theory and Practice, 27(6), 1105 1121.

Gbadamosi, A. (2012). Acculturation: An exploratory study of clothing consumption among Black African women in London (UK). Journal of Fashion Marketing and Management, 16(1), 1361-2026.

Hansen, K. T. (1999). Second hand clothing encounter in Zambia: Global discourses, western commodities and local history. Journal of the International Africa Institute, 69(3), 343365.

Herjanto, H. (2014). Decisions to commit digital piracy: The role of emotions and virtues. Doctor of Philosophy thesis. Auckland University of Technology, Auckland, New Zealand.

Herjanto, H., Scheller-Sampson, J., \& Erickson, E. (2016). The increasing phenomenon of second hand clothes purchase: Insights from the literature. Jurnal Manajemen dan Kewirausahaan, 18(1), 1-15.

Huang, X., \& Liu, X. (2016). Consumption and social integration: Empirical evidence for Chinese migrant workers. Economics Discussion Papers 2016-11, 1-26.

International Monetary Fund: IMF (2018). Indonesia. Retrieved from https://www.imf.org/en/Publications/CR/Issues/2018/02/06/Indonesia-2017-Article-IVConsultation-Press-Release-Staff-Report-and-Statement-by-the-45614.

Kapila, U. (2002). Globalization and the Indian economy. In R. Kapila \& U. Kapila (Eds.), India's economy in the $21^{\text {st }}$ century: A collection of select articles (pp. 426-438). New Delhi, Academic Foundation. 
Karimah, N. U., \& Safrizal. (2014). Motivasi masyarakat membeli pakaian bekas di pasar Senapelan Pekanbaru. Journal Online Mahasiswa Fakultas Ilmu Sosial dan Ilmu Politik Universias Riau, 1(1), 1-15.

Kestenbaum, R. (2018). Secondhand clothes are a threat and an opportunity. Retrieved from https://www.forbes.com/sites/richardkestenbaum/2018/04/03/secondhand-clothes-are-athreat-and-an-opportunity/\#136a5e56fdd0.

Kharullah, D. Z., \& Kharullah, Z. Y. (1999). Relationships between acculturation, attitude toward the advertisement, and purchase intention of Asian-Indian immigrants. International Journal of Commerce and Management, 9(3\&4), 46-65.

Kim, Y. Y. (2001). Becoming intercultural: An integrative theory of communication and crosscultural adaptation. Thousand Oaks, CA, Sage.

Kim, Y. (2011). Understanding green purchase: The influence of collectivism, personal value and environmental attitudes, and the moderating effect of perceived consumer effectiveness. Seoul Journal of Business, 17(1), 65-92.

Kiylioglu, L., \& Wimmer, H. (2015). The relationship between immigration, acculturation and psychological well-being. The case of Turkish youth in Austria. Nesre, 3(5), 1-19.

Kjeldgaard, D. (2002). Youth identities and consumer culture: Navigating local landscapes of global symbols. Advances in Consumer Research, 29, 387-392.

Koe, W. L., Sa'ari, J. R., Majid, I. A., \& Ismail, K. (2012). Determinants of entrepreneurial intention among millennial generation. Paper presented at Asia Pacific Business Innovation and Technology management, Pattaya, Thailand.

Manrai, A. K., \& Manrai, L. A. (2011). Cross-cultural and cross-national consumer research in the global economy of the twenty first century. Journal of International Consumer Marketing, 23(4), 167-180.

McGorry, S. Y. (2000). Measurement in a cross-cultural environment: Survey translation issues. Qualitative Market Research: An International Journal, 3(2), 74-81.

Na'amneh, N. M., \& Al Huban, A. K. (2012). Identity in old clothes: The socio-cultural dynamics of second-hand clothing in Irbid, Jordan. Social Identities, 18(5), 609-621.

Nameghi, E. N. M. \& Shadi, M. A. (2013). Affective and cognitive: Consumers attitude toward practicing green (reducing, recycling \& reusing). International Journal of Marketing Studies, 5(1), 157-164.

Nik Abdul, R. N. A., Jusof, K., \&Kassim, K. M. (2009). Eco-labelling perspectives amongst Malaysian consumers, Canadian Social Science, 5(2), 1-10.

Nikkei Asian Review. (2015). Indonesians splurge when monthly income passes \$375. Retrieved from https://asia.nikkei.com/Business/Consumers/Indonesians-splurge-when-monthlyincome-passes-375.

Ogden, D. T., Ogden, J. R., \& Schau, H. J. (2004). Exploring the impact of culture and acculturation on consumer purchase decisions: Toward a microcultural perspective. Academy of Marketing Science Review, 2004(3), 1-22.

O'Rourke, K. H., \& Williamson, J. G. (2004). Once more: When did globalization begin? European Review of Economic History, 8, 109-117.

Osland, J. S. (2003). Broadening the debate: The pros and cons of globalization. Journal of Management Inquiry, 12(2), 137-154.

Owaka, M. (2015). Black African immigrants' acculturation and psychosocial functioning: A clinical literature review. (Doctor of Philosophy thesis, Azusa Pacific University). Retrieved from https://search-proquest-com.ezproxy.aut.ac.nz/docview/1758046460/ previewPDF/71C034F9B15F4A5CPQ/1?accountid=8440. 
Presley, A. B., \& Campassi, W. U. (2013). Measuring clothing color and design symbolism preferences and purchase intentions of Asian Indian females at different levels of acculturation. ISRN Textiles, 2013, 1-8.

Rajan, R. (2001). Economic globalization and Asia: Trade, finance and taxation (CIES Discussion Paper No. 0150). Retrieved from https://www.adelaide.edu.au/cies/ documents/papers/0150.pdf.

Rizwan, M., Mahmood, U., Siddiqui, H., \& Tahir, A. (2014). An empirical study about green purchase intention. Journal of Sociological Research, 5(1), 290-305.

Ryding, D., Wang, M., Fox, C., \& Xu, U. (2017). A review of secondhand luxury and vintage clothing. In C.E. Henninger, P.J. Alevizou, H. Goworek \& D. Ryding (Eds.), Sustainability in Fashion. (pp. 245-266). Cham, Switzerland, Palgave MacMillan.

Saffu, K., \& Walker, J. (2006). The country of origin effects and consumer attitude to buy local campaign: The Ghanaian case. Journal of African Business Studies, 7(1-2), 183-199.

Saputra, A. (2015). Lebaran 2015, artis - artis ini pakai baju bekas. Retrieved from https:/www.liputan6.com/showbiz/read/2272770/lebaran-2015-artis-artis-ini-pakaibaju-bekas.

Sharpe, J. (2014). Asia and Pacific: Meet Indonesia's middle class. Retrieved from https://www.lowyinstitute.org/the-interpreter/meet-indonesias-middle-class.

Stets, J. E. \& Burke, P. J. (2000). Identity theory and social identity theory. Social Psychology Quarterly, 63(3), 224-237.

Tanrisever, S. (2015). A sustainable design technique for recycling of waste clothes. The Macrotheme Review, 4(5), 170-178.

The World Bank. (2000). Global economic prospects and the developing countries 2000 (pp. 1422). New York, Oxford University Press.

The World Bank. (2017a). December 2017 Indonesia economic quarterly: Decentralization that delivers. Retrieved from http: //www.worldbank.org/en/country/indonesia/publication/ indonesia-economic-quarterly-december-2017.

The World Bank. (2017b). Indonesia's middle class vital for the country's future. Retrieved from http://www.worldbank.org/en/news/press-release/2017/12/04/indonesia-middle-classvital-for-the-country-future.

ThredUp. (2016). Smart style: Celebs who shop secondhand. Retrieved from https://www.thredup.com/bg/p/celebrities-shopping-secondhand.

Tian, K. T., Bearden, W. O., \& Hunter, G. L. (2001). Consumers' need for uniqueness: Scale development and validation. Journal of Consumer Research, 28(1), 50-66.

Toplis, A. (2010). A stolen garment or a reasonable purchase? The male consumer and the illicit second-hand clothing marketing in the first half of the nineteenth century. In J. Stobart \& I. Van Damme (Eds.), Modernity and the secondhand trade. (pp. 57-72). London, Macmillan.

Van Elven, M. (2018). Second hand fashion set to become a bigger market than luxury by 2022. Retrieved from https://fashionunited.uk/news/business/second-hand-fashion-set-tobecome-a-bigger-market-than-luxury-by-2022/2018102339591

Wan, C., Shen, G. Q., \& Choi, S. (2017). Experiential and instrumental attitudes: Interaction effect of attitude and subjective norm on recycling intention. Journal of Environmental Psychology, 50, 69-79.

Watson, D., Palm, D., Brix, L., Amstrup, M., Syversen, F., \& Nielsen, R. (2016). Exports of Nordic used textiles: Fate, benefits and impacts. (pp. 1-247). Copenhagen, Nordisk Ministerrad. 
Wisnuwardhani, L., Suyadi, I., \& Sunarti. (2015). Upaya peningkatan penjualan baju bekas melalui media Facebook. Jurnal Admisintrasi Bisnis, 1(1), 1-8.

Wu, J. H., Wu, C. W., Lee, C. T., \& Lee, H. J. (2015). Green purchase intentions: An exploratory study of the Taiwanese electric motorcycle market. Journal of Business Research, 68, 829-833.

Yan, R. N., Bae, S. Y., \& Xu, H. (2015). Second hand clothing shopping among college students: The role of psychographic characteristics. Young Consumers, 16(1), 85-98. 